\title{
Antimicrobial agents from Malaysian plants and their potential use in food packaging material: Review
}

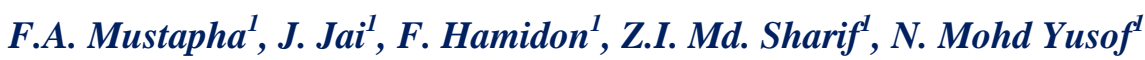

${ }^{I}$ Department of Chemical Engineering, University of Technologi MARA, 40450, Shah Alam, Selangor, Malaysia. Article Info: Submitted on March 20, 2017, Accepted on June 20, 2017.

\begin{abstract}
Malaysia is among 12 countries in the world that rich in biodiversity including an assortment of plants with potential sources for new antimicrobial agents. Despite the fact that various plants have been screened, the requirement for detail study on antimicrobial compounds from plants is preceded as safer and better agent to inhibit growth of microbes. Therefore, selected Malaysia plants with medicinal properties are listed for further review in their antimicrobial activity and their major compound that act as antimicrobial agent. The major groups of the antimicrobial constituents are phenolics, phenolic acids, quinones, saponins, flavonoids, tannins, coumarins, terpenoids and alkaloids. These compounds are secondary metabolites that play the main role in plant defense mechanism. They also exhibited inhibitory effect on various microorganisms such as Staphylococcus aureus, Bacillus subtilis, Pseudomonas aeruginosa, Escherichia coli and Candida albicans. Compounds derived from Malaysian plants have the potential to be used as antimicrobial additive as most of their extracts containing active compounds such as caffeic acid, pyrogallol, catechin and curcumin. Extraction method of plants extract is done either by conventional method of maceration and extraction under reflux and steam distillation or modern method of microwave assisted extraction, supercritical fluid extraction and ultrasound-assisted solvent extraction. Even though plants extracts with medicinal properties are gaining fame for their antimicrobial properties, however the study on incorporation of the extracts into edible films as antimicrobial food packaging is limited. The advantages of using an edible film with antimicrobial agent plants for food products are it safe to use and it able to extend the shelf life while reducing packaging waste.
\end{abstract}

Keywords: Malaysian plants; Antimicrobial; Food packaging; Natural sources; Plant extract.

\section{Introduction}

Food spoilage is commonly caused by microbial contamination during slaughtering, processing, packaging and shipping. Growth of a group of microorganisms including foodborne pathogens due to mishandling and misuse of antibiotics lead to formation of microbes that have a good tolerant with food processing and preservation besides exhibit antibiotic resistant. Counter measure taken by food industry are usually by thermal processing, refrigeration, freezing, modified atmosphere, drying, salting and fermentation. ${ }^{1}$ Even though this method helps to extend the shelf life of food products, however they cannot totally inhibit the growth of pathogenic microbes that can endanger the consumer's health.

Adding antimicrobial agentto food is one of the alternative technologies to suppress the microbial activity. However, this type of additive is commercially limited. Common chemical food preservative uses in food are benzoic acids, sorbic acids, sulphur dioxide, nitrates and nitrites, and their derivative salts. ${ }^{2}$ However, these synthetic chemical additives are potential allergens such as benzoic acid and sulphites. These additives lead to formation of carcinogenic compounds of nitrosamines from nitrite and benzene from benzoic acid. Excessive consumption of these chemical additives potentially causes adverse effect on the consumer's health. Quality, nutritional and safety of food are the reasons of the continuously expanding interest for the researcher to study into natural antimicrobial compounds usage in food.

Antimicrobial additive from plant origin is a promising green technology for food industry. Studies related to plant-derived antimicrobials found in scientific literature commonly encompassing the antimicrobial activity of herbs, spices and their derived essential oil and isolated compounds. ${ }^{3,4}$ This is due to the large number of secondary metabolites found in spices and herbs that can inhibit the growth of infectious organisms. ${ }^{4,5}$ Beth et al. ${ }^{6}$ stated that most of the recent research to discover additional natural antimicrobialagents are from plant with medicinal properties. Most plant that exhibit medicinal properties have inhibitory effect on various types of microorganism.

Malaysian rainforest is among the richest flora in the world where it encompasses several thousand species of vascular plants. This includes more than 2,000 species of trees as well as the parasitic monster flower Rafflesia arnoldii (Rafflesiaceae family), numerous varieties of carnivorous pitcher plants Nepenthes, 100 different species of trees in one acre of forest (shrubs, 


\section{Chemical Engineering Research Bulletin 19(2017) 57-66}

herbs, creepers and epiphytes) etc. ${ }^{7}$ Previous study on antimicrobial screening of 93 plants listed in Malaysia which majority of the plants have been used in traditional medicine or as food summarize that only $12 \%$ from the plants do not exhibit antimicrobial activity. ${ }^{8}$ Malaysia encompasses wide range of herbs that exhibit medicinal properties such as Curcuma longa, Ocimum basilicum, Labisia pumila etc. Different plant has different degree of antimicrobial ability based on their congenital active compounds. Therefore, researcher tends to use unnecessary excessive amount of the plants to the food in order to have high amount of active compounds. According to this, Beth et al. ${ }^{6}$ suggested that the identified active compound need to be isolated and concentrated first prior to antimicrobial activity study. Some of the extracts may have adverse flavor or odor and change the organoleptic properties of the foods product. To overcome this problem, Gyawali and Ibrahim $^{9}$ suggested that plants antimicrobial compound should be combined with others natural preservative or technologies in order to produce synergistic effect against foodborne pathogens.

Antimicrobial food packaging systems is a packaging system designed to release the antimicrobial compound on the food surface to inhibit or to delay the microbial growth. ${ }^{10}$ In general, there are two approaches to prevent microorganisms from infecting humans or deteriorating food products; disinfection and antimicrobial polymers. ${ }^{11}$ However, the usages of disinfectants cause a considerable environmental pollution problem and boost the development of resistant microbial strains. Meanwhile, the second method is generally formulated by incorporation of materials with biocides onto polymers and then discharged into the surroundings to inhibit or to kill microbes. The main advantage of antimicrobial polymers is that it can be tethered to polymer surfaces without affecting their biological activity and can kill microbes without discharging the antimicrobial agent. ${ }^{11}$ In this review, several Malaysian plants that are recognized as the potential sources for antimicrobial agent to be incorporated into food packaging material are presented. The related extensive researches on the antimicrobial compounds of these plants are also reviewed in details.

\section{Antimicrobial Activity of Malaysian Plants}

Plants containing phytochemicals are important especially those that have beneficial medicinal effects. Phytochemical is a part of non-nutritive plants that biologically active which also act as antimicrobial agents in plant defense mechanism. ${ }^{5,12}$ Phytochemical is resulted from combination of secondary products present in plant. They are secondary metabolites, which beenproduced and appended either in particular parts or in all parts of the plants. Some of the major groups for secondary metabolites in plants are phenolic, terpenoids and alkaloids compound. ${ }^{12} \mathrm{~A}$ number of studies and reviews have been conducted on phytochemical as natural antimicrobial agent due to the increasing consumer demand for safer food additive. ${ }^{4,5,9,12-17}$ Tana et al. ${ }^{5}$ brings to the fore the fact that antimicrobial activity is depending on the compounds concentration, structure, functional group and composition. Even though study by Ciocan and Bara $^{12}$ highlighted that essential oil have been used worldwide as food preservative since ancient times and alkaloids also commonly used as antimicrobial agent in foods product, however study by Halley and Patel ${ }^{18}$ highlighted that phenolic compounds are the most effective phytochemical. Therefore, it is importance to screen randomly the plants for active compound instead of screening botanically the targeted species.

Cananga odorata (Lam.) Hook. f. \& Thomson. (Annonaceae family). C.odorata is commonly known as 'kenanga' (Malay) and 'ylang' (English). C.odorata is a tree with height $2-4 \mathrm{~m}$ with dark green leaves and yellow brownish fragrant flower when mature. The taste of this tree is slightly numbing. ${ }^{19}$ Study by Sacchetti et $a l^{20}$ on antimicrobial activity of C.odorata flower oil by disc diffusion assay method show that it can inhibit growth of Candida albicans, Rhodotorula glutinis, Schizosaccharomyces pombe, Saccharomyces cerevisiae, Yarrowia lypolitica with minimum inhibition concentration (MIC) of 0.17, 0.23, $0.54,0.27$ and $0.3 \mathrm{mg} / \mathrm{mL}$ respectively. Antimicrobial activity of 'ylang' is attributed by the presence of caffeic acid (phenolic compound) and camphene and $\beta$-pinene (terpenoid compounds).

Cosmos caudatus Kunth (Asteraceae family). $C$. caudatusalso known as 'ulam raja' (Malay) and Indian Pennywort in English can grow up to $3 \mathrm{~m}$ tall. The dried leaves powder has a unique odor and mint taste. ${ }^{21}$ Study by Rasdi et $a l .{ }^{22}$ which use dimethyl sulfoxide as the negative control show that $C$. caudatus exhibit antimicrobial activity on Staphylococcus aureus, Bacillus subtilis, Pseudomonas aeruginosa, Escherichia coli and Candida albicans with minimum inhibition concentration of $25 \mathrm{mg} / \mathrm{mL}$ for all bacterial strains. The antimicrobial activity is due to the presence of chlorogenic acid and catechin from phenolic and flavonoid compounds, respectively.

Kaempferia galangal L. (Zingiberaceae family). $K$. galanga is a small herb which also known as 'cekur' in Malay and East-Indian galangal in English. This tree powder is light brown in color and has taste of slightly spicy and astringent. The rhizome is fleshy and fragrant pale green or greenish white inside. Antimicrobial activity of $K$. galanga affects different microorganisms at different minimum inhibitory concentration (MIC) depending on the part of tree extracts tested and the solvent used. Study by Omar et $a .^{23}$ on $200 \mu \mathrm{L}$ essential oil of $K$. galanga rhizome 


\section{Chemical Engineering Research Bulletin 19(2017) 57-66}

exhibit antimicrobial effect to Staphylococcus aureus and Bacillus cereus with MIC of $333 \mu \mathrm{g} / \mathrm{mL}$ and Pseudomonas aeruginosa, Escherichia coli and Candidaalbicans with MIC of $111 \mu \mathrm{g} / \mathrm{mL}$ by disc diffusion method. Active compound of K. galanga are phenylpropanoids (phenolic compound), dipentene dioxide (terpenoid compound) and 3, 7dimethoxycoumarin (coumarin compound).

Curcuma longa $\mathbf{L}$. (Zingiberaceae family). C.longa is commonly known as 'kunyit' in Malay and turmeric in English. The rhizome is bright yellow in color with aromatic odor and has bitter taste where the plant can growth up to $1 \mathrm{~m} \cdot{ }^{24,25}$ Antimicrobial activity of turmeric is proved in study by Singh et $\mathrm{l}^{24}$ on essential oil of C.longa rhizome, where the study demonstrated that it can inhibit the growth of Staphylococcus aureus with MIC of $1.95 \mu \mathrm{L} / \mathrm{L}$, Candida albicans with MIC 5.5 $\mu \mathrm{L} / \mathrm{L}$ and Aspergillus niger with MIC $6.7 \mu \mathrm{L} / \mathrm{L}$. Antimicrobial activity of turmeric is attributed by the presence of curcumin, a phenolic compound also sesquiterpene, terpenes compounds.

Labisia pumila (Primulaceae family).L. pumila also known as 'kacip Fatimah' in Malay where it has tough and woody root, light brown in color, has slight odour and tasteless. ${ }^{26}$ The tree's growth rate very low and can erect up to $10-40 \mathrm{~cm}$ high or prostrate up to $60 \mathrm{~cm}$ long. ${ }^{27}$ Antimicrobial activity of methanol extracts of L. pumila var. alataroot and stem $(300 \mathrm{mg} / \mathrm{disc})$ indicated direct inhibitory action againstBacillus subtilis and Bacillus cereus (Gram-positive bacteria) with inhibition zone ranging from $0.79-0.94 \mathrm{~cm}$ while Enterobacter aerogenes, Escherichia coli and Klebsiella pneumonia (Gram-negative bacteria) with inhibition zone ranging from 0.50 to $1.11 \mathrm{~cm} .{ }^{28}$ The antimicrobial activity is due to the presence of gallic acid and myricetin from phenolic and flavonoid compounds, respectively.

Melastoma malabathricum L.(Melastomataceae family). M. malabathricum is small tree 2-5 $\mathrm{m}$ tall and also known as 'senduduk' (Malay) and straits rhododendron (English). The dried powder is tasteless and has characteristic odor. ${ }^{29}$ Antimicrobial activity of $200 \mathrm{mg} / \mathrm{mL}$ aqueous extract of M. malabathricum leaves has been studied by Thatoi et al. ${ }^{30}$ In the study, it is shown that the extract restrained the growth of Bacillus brevis with inhibition zone of $21 \mathrm{~mm}$, Vibrio cholera $(20 \mathrm{~mm})$, Candida kruesi $(13 \mathrm{~mm})$ and $B$. subtilis $(13 \mathrm{~mm})$ by applying agar cup method.Antimicrobial activity of straits rhododendron are attributed by the presence of asiatic acid, terpene compound; quercetin, flavonoids compound and strictinin, tannin compounds.

Morinda citrifolia Linn. (Rubiaceae family).The plant is also known as 'mengkudu' (Malay) or Indian mulberry (English). It can growth up to $3-10 \mathrm{~m}$ in shady forests, open rocky shores and also sandy shores. ${ }^{31} M$. citrifolia fruit color is yellow to green and have bitter taste while the ripe fruit has a strong butyric acid-like rancid smell. ${ }^{31} 100 \mathrm{mg} / \mathrm{mL}$ methanol extracts of $M$. citrifolia fruit exhibit strong antimicrobial activity against Salmonella paratyphi A (gramnegative bacteria) and moderate activity against Salmonella typhi, Escherichia coli, Vibrio harveyi, Klebsiella pneumonia, Shigella flexneri, Salmonella paratyphi A, Aeromonas hydrophilam, Vibrio cholera, Chromobacterium violaceum and Enterobacter faecalis (others gram-negative bacteria) and Bacillus subtilis, Staphylococcus aureus, Lactobacillus lactis, Streptococcus thermophilus, Pseudomonas aeruginosa (gram-positive bacteria). ${ }^{32}$ Active compound of Indian mulberry are quercetin (flavonoid compound), xeronine (alkaloid compound) and terpineol (terpene compound).

Murraya koenigii (L.)Sprengel (Rutaceae family) also known as 'daun kari' (Malay) or curry leaves (English). M. koenigii is a tree with height ranging from 4 to $6 \mathrm{~m}$ where the powder is green in color with aromatic odor and slightly pungent and bitter taste. ${ }^{33}$ Disc diffusion method is used to identify the antimicrobial activity of ethanol (90\%) extract of 50 $\mathrm{mg} / \mathrm{mL}$ M. koenigii leaves by Argal et al..$^{34}$ showed that it inhibited the growth of Staphylococcus aureus with inhibition zones of $16 \mathrm{~mm}$ and Escherichia coli $(18 \mathrm{~mm})$. Active compound of curry leaves are quercetin (flavonoid compound), carbazole (alkaloid compound) and cinnamic acid (phenolic compound).

Most of the Malaysian plant have phenolic compound as active component except for Indian mulberry. Phenolic compounds are simple bioactive phytochemicals with one substituted phenolic ring. ${ }^{35}$ Cabral et $a l .{ }^{36}$ suggested that phenolic compound in defense mechanism is through enzyme inhibition cause by oxidized compound. The hydrophobic natures of the phenolic compounds allow them to make alteration on the microbial cellular permeability by penetrating into microbial cells and causes loss of macromolecules. Then, the compounds make interactions with membrane proteins resulting in structural and functionality changes. While Cowan ${ }^{37}$ suggested that compound with higher oxidation bestow on greater inhibition of microorganism growth, Tana $e t$ $a l^{5}$ make a hypothesis that toxicity increases with increased hydroxylation. They also clarify that degrees of toxicity to microorganism is related to the number and sites of hydroxyl groups on the phenolic ring. The major group and active compounds, antimicrobial activity and the applications of some Malaysian plant are listed in Table 1 . 


\section{Chemical Engineering Research Bulletin 19(2017) 57-66}

Table 1: List of Malaysian plants, their active compound and antimicrobial activity against different microorganisms.

\begin{tabular}{|c|c|c|c|c|c|c|c|}
\hline Plants & Plant parts & Major group & Active compound & Targeted microorganism & Inhibition activity & Applications & References \\
\hline Ylang & Flowers & $\begin{array}{l}\text {-Phenolic } \\
\text {-Terpenoid }\end{array}$ & $\begin{array}{l}\text { - Caffeic acid } \\
\text { - Camphene and } \beta \text {-pinene }\end{array}$ & $\begin{array}{l}\text { Candida albicans } \\
\text { Rhodotorula glutinis } \\
\text { Schizosaccharomyces pombe }\end{array}$ & $\begin{array}{l}0.17 \mathrm{mg} / \mathrm{mL} \\
0.23 \mathrm{mg} / \mathrm{mL} \\
0.54 \mathrm{mg} / \mathrm{mL}\end{array}$ & -Medicinal use & 20 \\
\hline Indian Pennywort & Leaves & $\begin{array}{l}\text {-Flavonoids } \\
\text {-Phenolic }\end{array}$ & $\begin{array}{l}\text { - Catechin and quercetin } \\
\text { - Chlorogenic acid }\end{array}$ & $\begin{array}{l}\text { Staphylococcus aureus } \\
\text { Bacillus subtilis } \\
\text { Escherichia coli } \\
\text { Candida albicans }\end{array}$ & $\begin{array}{l}25 \mathrm{mg} / \mathrm{mL} \\
25 \mathrm{mg} / \mathrm{mL} \\
25 \mathrm{mg} / \mathrm{mL} \\
25 \mathrm{mg} / \mathrm{mL}\end{array}$ & $\begin{array}{l}\text {-Medicinal use } \\
\text {-Asian traditional food }\end{array}$ & 22 \\
\hline $\begin{array}{l}\text { East-Indian } \\
\text { galangal }\end{array}$ & Rhizomes & $\begin{array}{l}\text {-Phenolic } \\
\text {-Terpenoid } \\
\text {-Coumarin }\end{array}$ & $\begin{array}{l}\text { - Phenylpropanoids } \\
\text { - Dipentene dioxide } \\
\text { - 3,7-dimethoxycoumarin }\end{array}$ & $\begin{array}{l}\text { Staphylococcus aureus } \\
\text { Bacillus cereus } \\
\text { Pseudomonas aeruginosa } \\
\text { Escherichia coli } \\
\text { Candidaalbicans }\end{array}$ & $\begin{array}{l}0.33 \mathrm{mg} / \mathrm{mL} \\
0.33 \mathrm{mg} / \mathrm{mL} \\
0.11 \mathrm{mg} / \mathrm{mL} \\
0.11 \mathrm{mg} / \mathrm{mL} \\
0.11 \mathrm{mg} / \mathrm{mL}\end{array}$ & $\begin{array}{l}\text {-Medicinal use } \\
\text {-Flavoring in Asian dishes }\end{array}$ & 23 \\
\hline Turmeric & Rhizomes & $\begin{array}{l}\text {-Terpenes } \\
\text {-Phenolic }\end{array}$ & $\begin{array}{l}\text { - Sesquiterpene } \\
\text {-Curcumin }\end{array}$ & $\begin{array}{l}\text { Staphylococcus aureus } \\
\text { Candida albicans } \\
\text { Aspergillus niger }\end{array}$ & $\begin{array}{l}1.95 \mathrm{mg} / \mathrm{mL} \\
5.50 \mathrm{mg} / \mathrm{mL} \\
6.70 \mathrm{mg} / \mathrm{mL}\end{array}$ & $\begin{array}{l}\text {-Medicinal use } \\
\text {-Flavoring in Asian dishes } \\
\text {-Cosmetic }\end{array}$ & 24,25 \\
\hline 'Kacip Fatimah' & Roots & $\begin{array}{l}\text {-Flavonoids } \\
\text {-Phenolic }\end{array}$ & $\begin{array}{l}\text { - Myricetin } \\
\text { - Gallic acid and pyrogallol }\end{array}$ & $\begin{array}{l}\text { Bacillus subtilis } \\
\text { Bacillus cereus } \\
\text { Enterobacter aerogenes } \\
\text { Escherichia coli } \\
\text { Klebsiella pneumonia }\end{array}$ & $\begin{array}{l}0.79-0.94 \mathrm{~cm} \\
0.79-0.94 \mathrm{~cm} \\
0.50-1.11 \mathrm{~cm} \\
0.50-1.11 \mathrm{~cm} \\
0.50-1.11 \mathrm{~cm}\end{array}$ & $\begin{array}{l}\text {-Medicinal use } \\
\text {-Used in food and } \\
\text { beverage }\end{array}$ & 28 \\
\hline $\begin{array}{l}\text { Straits } \\
\text { rhododendron }\end{array}$ & Leaves & $\begin{array}{l}\text {-Terpenes } \\
\text {-Flavonoids } \\
\text {-Tannins }\end{array}$ & $\begin{array}{l}\text { - Asiatic acid } \\
\text { - Quercetin } \\
\text { - Strictinin. }\end{array}$ & $\begin{array}{l}\text { Vibrio cholera } \\
\text { Candida kruesi } \\
\text { Bacillus subtilis }\end{array}$ & $\begin{array}{l}2.0 \mathrm{~cm} \\
1.3 \mathrm{~cm} \\
1.3 \mathrm{~cm}\end{array}$ & $\begin{array}{l}\text {-Medicinal use } \\
\text {-Asian traditional food }\end{array}$ & 30 \\
\hline Indian mulberry & Fruits & $\begin{array}{l}\text {-Flavonoids } \\
\text {-Alkaloids } \\
\text {-Terpenes }\end{array}$ & $\begin{array}{l}\text { - Quercetin } \\
\text { - Xeronine } \\
\text { - Ocimenol and terpineol }\end{array}$ & $\begin{array}{l}\text { Salmonella paratyphi } \\
\text { Escherichia coli } \\
\text { Vibrio cholera } \\
\text { Bacillus subtilis } \\
\text { Staphylococcus aureus } \\
\text { Lactobacillus lactis } \\
\text { Streptococcus thermophiles }\end{array}$ & $\begin{array}{l}\text { Strong } \\
\text { Moderate } \\
\text { Moderate } \\
\text { Moderate } \\
\text { Moderate } \\
\text { Moderate } \\
\text { Moderate }\end{array}$ & $\begin{array}{l}\text {-Medicinal use } \\
\text {-Nutritional supplements }\end{array}$ & 32 \\
\hline Curry leaves & Leaves & $\begin{array}{l}\text {-Alkaloids } \\
\text {-Flavonoids } \\
\text {-Phenolics }\end{array}$ & $\begin{array}{l}\text { - Carbazole } \\
\text { - Quercetin } \\
\text { - Gallic acid and cinnamic acid }\end{array}$ & $\begin{array}{l}\text { Escherichia coli } \\
\text { Bacillus subtilis } \\
\text { Klebsiella pneumoniae }\end{array}$ & $\begin{array}{l}1.6 \mathrm{~cm} \\
1.6 \mathrm{~cm} \\
1.6 \mathrm{~cm}\end{array}$ & $\begin{array}{l}\text {-Medicinal use } \\
\text {-Flavoring in Asian dishes }\end{array}$ & 34 \\
\hline
\end{tabular}




\section{Chemical Engineering Research Bulletin 19(2017) 57-66}

According to Cueva et al. (2010), position of $-\mathrm{OH}$ group substitution in the aromatic ring and length of saturated side chain are the significant factors for antimicrobial activity. ${ }^{38}$ Olasupo et al. ${ }^{39}$ compared the efficacy of 5 natural compounds against the E.coli and Salmonella typhimurium identified that thymol are the most efficient, follow by carvacrol, eugenol, cinnamic acid and diacetyl. ${ }^{39}$ Even though thymol and carvacrol have similar structure, however both compounds exhibit difference antimicrobial effectiveness against microorganisms when tested in agar medium. Dorman and Deans (2000) concluded that the difference in effectiveness of antimicrobial activity is due to different locations of $-\mathrm{OH}$ group i.e. in thymol at meta- position meanwhile in carvacrol at orthoposition. ${ }^{40}$ However, structure-function relationship in these compounds is yet to be well understood as this research area is limited.

Referring to Table 1, the major compounds that contribute to antimicrobial activity are flavones, phenolic, alkaloid and terpenoid and essential oil. Referring to Table 1, the highest inhibition of Candida albicansis Indian pennywort followed by turmeric, 'ylang' and East-Indian galangal. It is found that the antimicrobial activity of Indian pennywort toward Candida albicansis attributed by flavonoids compound. Flavanoid is flavones with $\mathrm{C}_{3}-\mathrm{C}_{6}$ aromatic ring linkage. ${ }^{5}$ These compounds are synthesized by plants as defense mechanism toward microbial infection. Thus, it is an understanding fact that they been found in vitro to have wide range antimicrobial substances against variety of microorganism. ${ }^{12}$

On the other hand, coumarin is a phenolic compound that can be found in East-Indian galangal. Coumarins are phenolic compounds encompassing of fused benzene and $\alpha$-pyrone ring. ${ }^{5,12}$ Opposite to simple phenolic compounds, level of toxicity of coumarin to microorganism does not depend on the degree of hydroxylation. ${ }^{36}$ Even though coumarin is known fromtheir anti-inflammatory, antithrombotic and vasodilatory activities, however several coumarin exhibited antimicrobial activities. Referring to Table 1 , only East-Indian galangal has coumarin as one of the major compound and the plant has lower inhibition activity toward Candida albicans and Escherichia coli in comparison with Indian Pennywort that have flavonoid compound.

Alkaloid is another major group that contributes to antimicrobial activity in plants.Alkaloid is heterocyclic nitrogen compounds with the most efficient and therapeutically significant plant compounds. Referring to Table 1, only Indian mulberry and curry leaves have alkaloid compounds which are xeronine and carbazole respectively. Even though they are extremely toxic as it have a marked therapeutic effect in minute quantities when at large amount, ${ }^{12}$ however, both of the plants are consumed since decades ago by Malay culture in form of fruit juice (Indian mulberry) and as flavoring (curry leaves) in Asian dishes. Since there is no remark on the toxicity to human, therefore both of this plant can be suggested as sources for edible antimicrobial agent.

Essential oils (EO) are secondary metabolites in plant which act as carrier for the fragrance of plants. ${ }^{12}$ In addition tofragrance provider in plants, EO also getting their fame from theirrole in spices flavor and aroma. Essential oil are typically found in compounds with isoprene structures such as terpenes with general chemical structure $\mathrm{C}_{10} \mathrm{H}_{16}$, diterpenes $\left(\mathrm{C}_{20}\right)$, triterpenes $\left(\mathrm{C}_{30}\right)$, tetraterpenes $\left(\mathrm{C}_{40}\right)$, hemiterpenes $\left(\mathrm{C}_{5}\right)$ and sesquiterpenes $\left(\mathrm{C}_{15}\right)$. When the compounds contain additional element, typically oxygen, it is known as terpenoids. Study by Cabral et al. ${ }^{36}$ on terpenoid identified that these compounds confer antimicrobial activity against bacteria, protozoa, fungi and also virus. In addition to that, studies by Knobloch et $a l^{41}$ and Sikkema et al. ${ }^{42}$ highlighted that EO has ability to react with lipids on the microbes' cell membrane and cause membrane permeability which lead to death of the cell.Research on EO by Delaquis et al. ${ }^{43}$ and Aburjai and Natsheh ${ }^{44}$ shows that EO has both antioxidant and antimicrobial activity. Delaquis et al. ${ }^{43}$ reported thatthe effectiveness of cilantro EO against Listeria monocytogenes, theyalso concluded that the antimicrobial properties of alcohol compound increases with molecular weight. Cabral et al. ${ }^{36}$ highlighted that essential oils consist of varies phytochemicals group and it is been suggested for the antimicrobial action approach of essential oil to attack multiple targets. From Table 1, half of reviewed plants have terpenes or terpenoid as major compounds which are 'ylang' flowers, East-Indian galangal, turmeric, straits rhododendron and Indian mulberry.

Referring to Table 1, the most reported compound that have ability to inhibit wide range of microorganisms growth are phenolic followed by terpenoid and flavonoid. Therefore, incorporation of plant extract containing both of these active compounds is economically benefited for food industry. Consequently, sources of active compound to inhibit growth of food pathogens should be from plants that exhibit relatively high levels of antimicrobial activity ${ }^{5}$. Studies done by Naz et al. ${ }^{45}$ on antimicrobial activity for different types of turmeric such as Kasur, Faisalabad and Bannu showed that even though all of the trees are from same species, however, they found that Kasur exhibit highestefficacy against all bacteria strains tested in comparison with others two. Other than structural composition, the methods used to extractthe antimicrobial compound also affects the antimicrobial compound efficacy. ${ }^{16,17,46}$

\section{Extraction Method}

Study by Gul and Bakht ${ }^{47}$ on extraction of turmeric rhizome highlight that water extracted turmeric 


\section{Chemical Engineering Research Bulletin 19(2017) 57-66}

inhibited the growth of E. coli and S. typhimeanwhile aqueous extract autoclaved at $121{ }^{\circ} \mathrm{C}$ for $30 \mathrm{~min}$ reduced the growth of E. coli and S. aureus. Therefore, in order to concentrate the desired phytochemical or antimicrobial compound, the most convenient and appropriate method should be screened prior to selection.

Extraction is a method where a desired substance is separated from its mixture by brought into contact with a solvent to form two immiscible phases. Thus the solvent must be soluble in the desired substance but insoluble with the other substances in the mixture. Extraction method has been used since thousand years ago by the ancient culture. 'Enfleurage' is one of the extraction method which means 'to saturate with the perfume of flowers'in French. ${ }^{48}$ Even 'Enfleurge' is the only method usedto extract from delicate flowers such as Jasmine flower, however, this method is very costly and time consuming. ${ }^{48,49}$ Other conventional extraction techniques are cold-pressing (fruit rinds are grind and press to extract the oils), soaking in alcohol or boiling water and steam distillation (steam are passing through the plant, steam condense, oil separates from the plant). ${ }^{49}$

With comparison to conventional method, the modern extraction methods such as Microwave Assisted Extraction (MAE), Supercritical Fluid Extraction (SFE) and Ultrasound Assisted Extraction (UAE) take shorter time and give better quality and yield of recovered extract. ${ }^{50}$ The extraction methods of active compounds and essential oils from plants either medicinal or aromatic plants are depending on the suitability of the process and types of botanical material. ${ }^{51}$ For example, maceration method is commonly used for massage and cooking oil and suitable for bulk extraction while extraction under reflux and steam distillation is commonly used to extract EO. On the other hand, UAE is typically used for initial extraction of material in small scale. ${ }^{52}$

The type of solvent is another important factor that affects the extraction yield. Extraction process occurred as diffusion of solvent into plant tissues and solubilize of compound of similar polarity takes place. Since plant cell wall exhibit non-polarity character, it degraded efficiently in organic solvent compared in water. In addition, organic solvent is more favorable in maximizing extraction of phenolic compound from plant material as some plant's substances are readily soluble in organic solvent. ${ }^{53}$

Lee et $a l .{ }^{54}$ review on plant extracts as natural antimicrobial agent highlighted that the best solvent to extract antimicrobial compound from most of the plants is methanol and the plant extracts without exposure to high temperature exhibit more effective antimicrobial activity i.e. SFE used supercritical fluid solvent and UAE used ultrasound to break the plant cell wall takes place at ambient temperature. In addition, these two methods increased the yield of extraction at relatively low-cost. ${ }^{55,56}$

\section{Antimicrobial Compound in Food Packaging}

One of the common ways to preserve food is by adding specific chemical to food products to achieve the inhibition of microbial growth and chemical reaction that can cause food spoilage.$^{57}$ The advantages of natural additives from plant extracts are less harmful to human and environment. Most of natural additives and their derivatives are classified as Generally Recognized as Safe (GRAS) substances. ${ }^{58}$ Therefore, it is worth to review the plants in Malaysia that contain antimicrobial compound as to see the potential of their extract to replace the chemical additives. Incorporation of antimicrobial compound from plants in food systems can be done either added directly into the food itself or by slow release from packaging materials. ${ }^{9}$

\section{Direct application}

Antimicrobials compound are directly applied in food systems either in powder form or liquid prior to the package being filled and sealed. This method are typically used in soft drink production and meat products. ${ }^{57}$ Study by Yuste and Fung ${ }^{59}$ on $0.1-0.3 \%$ $(w / v)$ of ground cinnamon in pasteurized apple juice reported in $6 \quad \log \mathrm{CFU} / \mathrm{ml}$ reductions of $L$. monocytogenes after $1 \mathrm{~h}$ of incubation, there are no further development of the microorganism is seen following in 7 days of storage. In addition, Cavaet $a l .{ }^{60}$ study on semi-skimmed milk mixed with essential oils against $L$. monocytogenes incubated for 14 days at $7^{\circ} \mathrm{C}$ revealed that MIC of 500ppm cinnamon bark and 3,000ppmfor both cinnamon leaf and clove.Karabagias et al. ${ }^{11}$ studies on the efficacy of thyme and oreganoshows that the shelf life of meat based food product is extended when dipped in EO. The findings of these studies highly suggest that EO can be used as natural antimicrobial agent in food products.

Gyawali and Ibrahim ${ }^{9}$ study on antimicrobial activity of compound from plant origin in food systems model stated that only a few of natural antimicrobials are practically applied in food industry. The limited usage of plant antimicrobial compounds is due to strong smell and undesirable aftertaste besides having poor solubility in complex food matrices. Gyawali and Ibrahim ${ }^{9}$ highlighted that plant extracts can be used as natural antimicrobial agent but the level of preservative required to significantly inhibit microbial growth must be considerably higher than the one used in laboratory media. In addition to that, the antimicrobial compound may not necessary for the interior part of food as most of microorganisms grow on the surface of food products. Therefore, it may cause an excessive use of preservative which then affect the quality of the foods. ${ }^{10}$ This disadvantage lead to major problem for the food industry where reduction 


\section{Chemical Engineering Research Bulletin 19(2017) 57-66}

in amount of natural preservative used will required additional preservation technique such as heating and freezing. However, both alternative methods will lead to unnecessary cost and result in foods with poorer quality. Since the higher concentration of antimicrobial compound negatively affects the organoleptic properties of foods, it is suggested that antimicrobial compounds from plants must be combined with other natural preservative or technologies in order to produce synergistic effect against the foodborne pathogens. $^{9}$

\section{Edible film and coating}

In food packaging system, the use of edible films as carrier to release the antimicrobial constituents is a form of active packaging. Since microbial growth in foods occurs mostly at the surface of the food items, ${ }^{62}$ research has been done with the goal to incorporate the antimicrobial substances into the food packaging to keep up quality and to delay the spoilage of the foods. This technique allows the antimicrobial compound to be concentrated at the surface of food where microbes usually grow and this may speed up the inhibition of spoilage microorganism. ${ }^{18}$ Generally, edible film and coating are made from renewable natural biopolymers such as protein, lipids, polysaccharides or the composite of these components. Edible films or coatings based on biopolymers development have gained interest mainly because of its friendliness to the environment and its potential to substitute petrochemical based material in food packaging industry.

Nilda ${ }^{63}$ reported that newly developed edible films incorporated with clove and oregano oils preserved bread longer than commercial additive, calcium propionate. After 10 days, Nilda identified that bread slice with commercial preservative lost its effectiveness but edible films containing small droplets of the oils continued to slow down the grow of mold. ${ }^{63}$ The study by Pranoto et al. ${ }^{64}$ on the minimum incorporation of garlic oil at $100 \mathrm{ml} / \mathrm{g}$ in chitosan showed that antimicrobial activity against $S$. aureus, $L$. monocytogenes and $B$. cereus. They also highlighted that garlic oil components did not affect the mechanical and physical properties of chitosan films as proven by FTIR analysis which showed no interaction of garlic oil with functional group of chitosan. ${ }^{64}$ Seydim and Sarikus ${ }^{65}$ studies on antimicrobial activity of whey protein based edible films incorporated with oregano, rosemary and garlic essential oils reported that film with oregano oil was the most effective against Escherichia coli O157:H7, Staphylococcus aureus, Salmonella enteritidis, Listeria monocytogenes and Lactobacillus plantarum at $2 \%$ level. In addition, Rojas-Grauet al. ${ }^{66}$ highlighted that presence of essential oil from plants significantly modify the tensile properties but does not affect the oxygen and water vapor permeability of films.
The previous decades have exhibited an alarming increment in the use of petrochemical-based synthetic packaging material such as polyethylene terephthalate, polyamide, polypropylene and polyethylene ${ }^{67}$ due to it effortlessly accessible in large amounts, cheap and have mechanical properties appropriate for commercial food packaging applications. However, these nonbiodegradable packaging materials endanger the environment. Thus, food companies everywhere throughout the world are striving to develop an alternate biodegradable food packaging systems, including edible films and coatings for foods. ${ }^{10}$

\section{Conclusion}

Active packaging such as antimicrobial packaging and controlled release packaging are promising technologies that can impregnate the antimicrobial compound into film material of food packaging and release the compound consistently over stipulated period of time to kill microbial that cause food spoilage. However, proper screening should be done during selecting and incorporating the antimicrobial compound into film of food packaging. Choosing the right antimicrobial compound to inhibit the targeted microbe or food-borne pathogens should be done in order to increase significantly shelf life of desired food products. Besides, if the targeted microbes have very short lag periods, it is not effective to choose a polymer which releases antimicrobial compound very slowly over a period of time. Also, if the antimicrobial compound is very compatible with the polymers that act as carrier, the antimicrobial compound may not be released at all or if it is incompatible the antimicrobial compound might be released rapidly therefore it defeats its main purpose to extend the shelf life of the food products. Even though spices and herbs extracts are fame for their antimicrobial properties, but study on application of the extracts into edible films is limited. ${ }^{65}$ Further researches on plant extract mode of releasing from packaging material are suggested. From this review, it can be concluded that the highlighted Malaysian plants did contained major group of antimicrobial compounds and can be used as sources for natural antimicrobial additives in foods. However, both structure-function and chemical compositionantimicrobial activity relationships of these compounds are yet to be established. Further research on Malaysia plants and the structural relationship between their antimicrobial compounds activities is suggested to identify the efficacy of each plants extract in food packaging.

\section{Acknowledgement}

Support from the Department of Chemical Engineering, University of Technology MARA, Shah Alam, Selangor, Malaysia and financial aid from 600- 


\section{Chemical Engineering Research Bulletin 19(2017) 57-66}

RMI/DANA 5/3/LESTARI (21/2015) are gratefully acknowledged.

\section{References}

1. S. Sung and L. Tin, "Antimicrobial agents for food packaging applications," vol. 10, pp. 1-14, 2013.

2. A. Cagri, Z. Ustunol, and E. T. Ryser, "Antimicrobial edible films and coatings," Journal of Food Protection, vol. 67, no. 4. pp. 833-848, 2004.

3. P. S. Negi, "Plant extracts for the control of bacterial growth: efficacy, stability and safety issues for food application,” International Journal of Food Microbiology, vol. 156, no. 1, pp. 7-17, 2012.

4. B. K. Tiwari, V. P. Valdramidis, C. P. O. Donnell, K. Muthukumarappan, P. Borke, and P. J. Cullen, "Application of Natural Antimicrobials for Food Preservation," Journal of Agricultural and Food Chemistry Review, vol. 57, no. 14, pp. 5987-6000, 2009.

5. H. Tana, K. K. Matthews, and R. Di, "The Use of Plant Antimicrobial Compounds for Food Preservation," BioMed Research International, vol. 2015, no. 246264, pp. 1-12, 2015.

6. A. C.-D. Beth, M. Carter, and Zuoxing Zheng, "Formulating Food Safety: An Overview of Antimicrobial Ingredients," Food Safety Magazine, Manhattan, pp. 1-7, 2005.

7. "Plant and animal life," Encyclopædia Britannica. [Online]. Available: http://global.britannica.com/place/Malaysia/Clim ate[Accessed: 12-Jun-2016].

8. M. Arifullah, P. Vikram, K. K. Chiruvella, M. M. Shaik, I. Husna, and B. A. Ripain, "A Review on Malaysian Plants Used for Screening of Antimicrobial Activity," vol. 4, no. 13, pp. 20882132, 2014.

9. R. Gyawali and S. A. Ibrahim, "Natural products as antimicrobial agents," Food Control, vol. 46, pp. 412-429, 2014.

10. R. Marathe, "Development of Controlled Release Antimicrobial Films from Low Methoxyl Pectin," Rutgers Graduate School-New Brunswick, 2008.

11. F. Siedenbiedel and J. C. Tiller, "Antimicrobial Polymers in Solution and on Surfaces: Overview and Functional Principles," Polymers (Basel), vol. 4, pp. 46-71, 2012.

12. I. D. Ciocan and I. I. Bara, "Plant Products as Antimicrobial Agents," Analele Ştiinţifice ale Universitatii,,Alexandru Ioan Cuza", Secţiunea Genet. şi Biol. Mol. TOM VIII, vol. 8, pp. 151-156, 2007.

13. F. Reyes Jurado, A. Franco-Vega, N. RamírezCorona, E. Palou, and Aurelio López-Malo, "Essential Oils: Antimicrobial Activities,
Extraction Methods, and Their Modeling," Food Engineering Reviews, vol. 6, no. 4, pp. 105-162, 2014.

14. A. Clinquart, "Antimicrobial activities of commercial essential oils and their components against food-borne pathogens and food spoilage bacteria," Food Science \& Nutrition, vol. 2, no. 4, pp. 403-416, 2014.

15. K. Das, R. K. S. Tiwari, and D. K. Shrivastava, "Techniques for evaluation of medicinal plant products as antimicrobial agent : Current methods and future trends," vol. 4, no. 2, pp. 104-111, 2010.

16. T. Nakatsu, A. T. Lupo, J. W. Chinn, and R. K. L. Kang, "Biological activity of essential oils and their constituents," Studies in Natural Products Chemistry, vol. 21, no. Part B, pp. 571-631, 2000.

17. K. A. Hammer, C. F. Carson, and T. V Riley, "Antimicrobial activity of essential oils and other plant extracts," Journal of Applied Microbiology, vol. 86, pp. 985-990, 1999.

18. R. A. Holley and D. Patel, "Improvement in shelf-life and safety of perishable foods by plant essential oils and smoke antimicrobials," Food Microbiol., vol. 22, no. 4, pp. 273-292, 2005.

19. S. Han, "Medicinal plants in the South Pacific," World Health Organization. Regional Publications, vol. 19, pp. 254, 1998.

20. G. Sacchetti, S. Maietti, M. Muzzoli, M. Scaglianti, M. Manfredini, M. Radice, and R. Bruni, "Comparative evaluation of 11 essential oils of different origin as functional antioxidants, antiradicals and antimicrobials in foods," Food Chemistry, vol. 91, no. 4, pp. 621-632, 2005.

21. W.E. Wan Hassan, "Healing herbs of Malaysia," Federal Land Development Authority (FELDA), pp.40, 2007.

22. N. Rasdi, O. Samah, A. Sule, and Q. Ahmed, "Antimicrobial studies of Cosmos caudatus Kunth. (Compositae)," Journal of Medicinal Plants Research, vol. 4, no. 8, pp. 669-673, 2010.

23. M. N. Omar, N. H. M. Hasali, H. Y. Alfarra, M. A. Yarmo, and A. M. Zuberdi, "Antimicrobial activity and microbial transformation of ethyl-pmethoxycinnamate extracted from Kaempferia galangal," Oriental Journal of Chemistry, vol. 30, no. 3, pp. 1037-1043, 2014.

24. K. Singh, B. Sankar, S. Rajesh, K. Sahoo, E Subudhi, and S. Nayak, "Chemical Composition of turmeric oil (Curcuma longa L. cv. Roma) and its antimicrobial activity against eye infecting pathogens," Journal of Essential Oil Research, vol. 23 , no. 6, pp. 11-18, 2012.

25. L. Shiyou, Y. Wei, D. Guangrui, W. Ping, Y. Peiying, and A. Bharat, "Chemical composition and product quality control of turmeric (Curcuma 


\section{Chemical Engineering Research Bulletin 19(2017) 57-66}

longa L.)," Pharmaceutical Crops, vol. 2, pp. 2854, 2011.

26. B. Stone, "Notes on the genus Labisia Lindl. (Myrsinaceae)," Malayan Nature Journal, vol. 42, no. 43, pp. 43-51, 1988 .

27. B. Sunarno, "Revision of the genus Labisia (Myrsinaceae)," Blumea, vol. 50, no. 3, pp. 579597, 2005.

28. E. Karimi, H. Jaafar, and S. Ahmad, "Phytochemical analysis and antimicrobial activities of methanolic extracts of leaf, stem and root from different varities of Labisia pumila Benth," Molecules, vol. 16, no. 6, pp. 4438-4450, 2011.

29. I. Burkill, "A Dictionary of the Economics Products of the Malay Peninsular," Kuala Lumpur, 1966.

30. H. Thatoi, S. Panda, S. Rath, and S. Dutta, "Antimicrobial activity and ethnomedicinal uses of some medicinal plants from Similipal Biosphere Reserve, Orissa," Asian Journal of Plant Sciences, vol. 7, no. 3, pp. 260-267, 2008.

31. J.F. Morton, "The ocean-going noni, or Indian mulberry (Morinda citrifolia, Rubiaceae) and some of its "“colourful", relatives," Ecological Botany, vol. 46, pp. 241-256, 1992.

32. S. Jayaraman, M. Manoharan, and S. Illanchezian, "Antibacterial, antifungal and tumor cell suppression potential of Morinda citrifolia fruit extracts," International Journal of Integrative Biology, vol. 3, no. 1, pp. 44-49, 2008.

33. S. Kumar, D. Loveleena, and S. Godwin, "Medicinal property of Murraya koenigii-A Review," International Research Journal of Biological Sciences, vol. 2, no. 9, pp. 80-83, 2013.

34. M. Argal, S. Kumar, H. Choudhary, R. Thakkar, S. Verma, and S. Seniya, "The efficacy of Murraya koenigii leaf extract on some bacterial and a fungal strain by disc diffusion method," Journal of Chemical and Pharmaceutical Research, vol. 3, pp. 697-704, 2011.

35. A. M. Galal, "Natural product-based phenolic and nonphenolic antimicrobial food preservatives and 1,2,3,4-tetrahydroxybenzene as a highly effective representative: a review of patent literature 20002005," Recent Patents on Anti-Infective Drug Discovery., vol. 1, no. 2, pp. 231-239, 2006.

36. L. D. C. Cabral, V. F. Pinto, and A. Patriarca, "Application of plant derived compounds to control fungal spoilage and mycotoxin production in foods," International Journal of Food Microbiology, vol. 166, no. 1, pp. 1-14, 2013.

37. M. M. Cowan, "Plant products as antimicrobial agents," "Clinical Microbiology Reviews, vol. 12, no. 4, pp. 564-582, 1999.

38. A. Cueva, C. Moreno-Arribas, M. Martín-
Alvarez, P. J. Bills, G. Vicente, M. F. Basilio and E. Al, "Antimicrobial activity of phenolic acids against commensal, probiotic and pathogenic bacteria," Research in Microbiology, vol. 161, no. 5, pp. 372-382, 2010.

39. N. A. Olasupo, D. J. Fitzgerald, M. J. Gasson, and A. Narbad, "Activity of natural antimicrobial compounds against Escherichia coli and Salmonella enterica serovar Typhimurium," Letters in Applied Microbiology, vol. 37, no. 6, pp. 448-451, 2003.

40. H. Dorman and S. Deans, "Antimicrobial agents from plants: antibacterial activity of plant volatile oils," Journal of Applied Microbiology, vol. 88, no. 2, pp. 308-316, 2000.

41. K.Knobloch, N.Weis, and H.Weigand, "Mechanism of antimicrobial activity of essential oils," Planta Medica, vol. 52, no. 6, pp. 556-566, 1986.

42. J. Sikkema, J. A. M. de Bont, and B. Poolman, "Interactions of cyclic hydrocarbons with biological membranes," Journal of Biological Chemistry, vol. 269, no. 11, pp. 8022-8028, 1994.

43. P. J. Delaquis, K. Stanich, B. Girard, and G. Mazza, "Antimicrobial activity of individual and mixed fractions of dill, cilantro, coriander and eucalyptus essential oils," International Journal of Food Microbiology, vol. 74, no. 12, pp. 101-109, 2002.

44. T. Aburjai and F. M. Natsheh, "Plants used in cosmetics," PhytotherapyResearch, vol. 17, no. 9, pp. 987-1000, 2003.

45. S. Naz, S. Jabeen, S. Ilyas, F. Manzoor, F. Aslam, and A. Ali, "Antibacterial activity of Curcuma longa varieties against different strains of bacteria," vol. 42, no. 1, pp. 455-462, 2010.

46. S. Burt, "Essential oils: their antibacterial properties and potential applications in foods: A review," International Journal of Food Microbiology, vol. 94, no. 3, pp. 223-253, 2004.

47. P. Gul and J. Bakht, "Antimicrobial activity of turmeric extract and its potential use in food industry," Journal of Food Science and Technology, vol. 52, no. 4, pp. 2272-2279, 2015.

48. "Essential Oils Extraction," 2008. [Online]. Available: http://www.answer-my-healthquestion.info/essential-oils-extraction.html. [Accessed: 14-Jun-2016].

49. N. Martin, "The Methods of Extracting Essential Oils are Still Being Proven," 2010. [Online]. Available: $\quad$ http://www.experience-essentialoils.com/methods-of-extracting-essentialoils.html. [Accessed: 14-Jun-2016].

50. A. Gupta, M. Naraniwal, and V. Kothari, "Modern extraction methods for preparation of bioactive plant extracts," International Journal of 


\section{Chemical Engineering Research Bulletin 19(2017) 57-66}

Applied and Natural Sciences, vol. 1, no. 1, pp. 8-26, 2012.

51. I. Kostova, "Synthetic and Natural Coumarins as Cytotoxic Agents," Current Medicinal Chemistry-Anti-Cancer Agents, vol. 1, pp. 2946, 2005.

52. S. Mahdi and Y. Altikriti, "Methods of extraction of natural product," Biologiskt Aktiva Naturprodukter i Läkemedelsproduktion HT2010 Introduction, vol. 20, pp. 3-5, 2010.

53. N. Amal, N. Mohamad, N. A. Arham, J. Jai, and A. Hadi, "Plant Extract as Reducing Agent in Synthesis of Metallic Nanoparticles : A Review," Advanced Materials Research, vol. 832, pp. 350355, 2014

54. W. Lee Seong, N. Musa, W. Wee, C. T. Seng, and N. A. Shazili, "Review on Plant Extracts as Natural Antibacterial Agent 1,”中国科技论文在线, vol. 2, pp. 1-6, 2006.

55. S. S. Handa, "Chapter 1: An Overview of Extraction Techniques for Medicinal and Aromatic Plants," in Extraction Technologis For Medicinal and Aromatic Plants, S. S. Handa, S. P. S. Khanuja, G. Longo, and D. D. Rakesh, Eds. Trieste, Italy: International Centre for Science and High Technology, 2008, pp. 21-27.

56. B. Hans-Jörg, "Extraction of Natural Products from Plants - An Introduction," in Industrial Scale Natural Products Extraction, 1st ed., H.-J. Bart and S. Pilz, Eds. Wiley-VCH Verlag GmbH \& Co. KGaA, 2011, pp. 1-26.

57. R. Coles, D. McDowell, and M. J. Kirwan, "Food Packaging Technology," in Packaging Technology Series, G. A. Giles and G. S. Kline, Eds. London, U.K, Blackwell Publishing, 2003, pp. 1-31.

58. "Overview of Food Ingredients, Additives and Colors," U.S. Food and Drug Administration, 2010. [Online]. Available: http://www.fda.gov/Food/IngredientsPackagingL abeling/FoodAdditivesIngredients/ucm094211.ht m\#how. [Accessed: 22-Jul-2016].

59. J. Yuste and D. Fung, "Inactivation of Listeria monocytogenes Scott A 49594 in apple juice supplemented with cinnamon," Journal of Food Protection, vol. 65, no. 10, pp. 1663-1666, 2002.

60. R. Cava, E. Nowak, A. Taboada, and F. MarinIniesta, "Antimicrobial activity of clove and cinnamon essential oils against Listeria monocytogenes in pasteurized milk.," Journal of Food Protection, vol. 70, no. 12, pp. 2757-2763, 2007.

61. I. Karabagias, A. Badeka, and M. Kontominas, "Shelf-life extension of meat using thyme or oregano essential oils and modified atmosphere packaging," Meat Science, vol. 88, no. 1, pp 109-116, 2011.

62. K. N. Turhan, "Cellulose Based Packaging Films Containing Natural," Journal of Hygienic Engineering and Design, vol. 5, pp. 13-17, 2013.

63. Nilda de F. F. Soares, "Edible Films from Methylcellulose and Nanoemulsions of Clove Bud (Syzygium aromaticum) and Oregano (Origanum vulgare) Essential Oils as Shelf Life Extenders for Sliced Bread," Journal of Agricultural and Food Chemistry, vol. 62, no. 22, pp. 5214-5219, 2014.

64. Y. Pranoto, S. K. Rakshit, and V. M. Salokhe, "Enhancing antimicrobial activity of chitosan films by incorporating garlic oil, potassium sorbate and nisin," LWT - Food Science and Technology, vol. 38, no. 8, pp. 859-865, 2005.

65. A. C. Seydim and G. Sarikus, "Antimicrobial activity of whey protein based edible films incorporated with oregano, rosemary and garlic essential oils," Food Research International Journal, vol. 39, no. 5, pp. 639-644, 2006.

66. M. A. Rojas-Grau, R. J. Avena-Bustillos, C. Olsen, M. Friedman, P. R. Henika, O. Mart. N.Belloso, Z. Pan, and T. H. McHugh, "Effects of plant essential oils and oil compounds on mechanical, barrier and antimicrobial properties of alginate-apple puree edible films," Journal of Food Engineering, vol. 81, no. 3, pp. 634-641, 2007.

67. S. Allahvaisi, "Polypropylene in the Industry of Food Packaging," Polypropylene, F. Dogan, Ed. InTech, 2012.

\section{Available online at http://www.banglajol.info/index.php/CERB}

Publisher: Department of Chemical Engineering, Bangladesh University of Engineering and Technology (BUET). Review \&Publication: A submitted original manuscript is taken into review only if the uniqueness is found to be more than $85 \%$ in plag-scanning and selected for publication by the complete acceptance from at least two reviewers out of three. Home Page: http://www.banglajol.info/index.php/CERB. Indexed by Chemical Abstract Service (CAS), CEABA-VtB, Google Scholar, Scopus and DOAJ. 